\title{
EFFECT of BLENDED Npsznb FERTILIZER and CATTLE Manure Rates on Growth, Yield and Quality of Potato (Solanum Tuberosum L.) at Banja District, Awi Zone, North Western Ethiopia
}

\author{
Bewket Getachew Bekele* \\ Pawe Agricultural Research Center, Ethiopian Institute of Agricultural Research, P.O.Box-25 Pawe, Ethiopia \\ *Corresponding Author: Bewket Getachew Bekele, Pawe Agricultural Research Center, Ethiopian \\ Institute of Agricultural Research, P.O.Box-25 Pawe, Ethiopia
}

\begin{abstract}
Potato (Solanum tuberosum L.) is a high potential food security crop in Ethiopia due to its high yield potential, nutritional quality, short growing period and wider adaptability. However its productivity is very low mainly due to low soil fertility. Based on the national soil database, most of North West Ethiopian soils are deficient in macronutrients $(N, P$ and $S)$ and micronutrients $(C u, B$ and $\mathrm{Zn})$ affecting growth, yield and quality of vegetables in general and potato in particular. Thus far, emphasis has not been given on assessing influence of combined application of inorganic and organic fertilizer on the growth, yield and quality of potato. Therefore, a field experiment was conducted to determine the appropriate rate of blended NPSZnB fertilizer and cattle manure (CM) on nitisol of Awi zone in 2017 under rainfed condition. The treatments consisted of four blended NPSZnB fertilizer rates (0, 65.7,133 and $\left.199 \mathrm{~kg} \mathrm{ha}^{-1}\right)$ and four CM rates $\left(0,10,20\right.$ and $\left.30 \mathrm{th} \mathrm{h}^{-1}\right)$. The experiment was laid out in $4 x 4$ factorial arrangements in randomized complete block design with three replications. Data on growth, yield and quality variables were collected and analyzed using SAS version 9.3 software. Results revealed that combined application of blended NPSZnB fertilizer and $C M$ significantly $(P<0.05)$ influenced days to 50\% flowering, days to maturity, plant height, leaf area index, marketable tuber yield, total tuber yield, tuber dry matter content and tuber starch content. However, main stem number and unmarketable yield were not affected by the combined application of NPSZnB blended

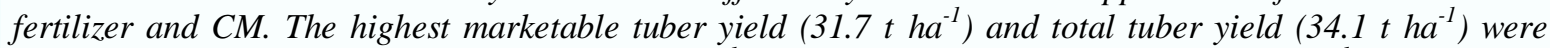
recorded from combined application of $199 \mathrm{~kg} \mathrm{ha}^{-1}$ of blended NPSZnB fertilizer and 30 tha of CM; while

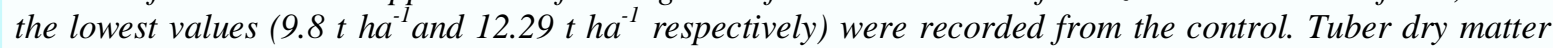
content and tuber starch content showed significant $(p<0.05)$ reduction with increased rate of combined application of blended NPSZnB fertilizer and CM. Correlation analysis showed that total tuber yield was highly significantly and positively correlated with plant height ( $r=0.903)$, leaf area index $(r=0.899)$, marketable yield $(r=0.950)$ and tuber starch content $(r=0.485)$. The result of this study verified that growth, yield and quality of potato were influenced by different blended NPSZnB fertilizer and CM rates. In conclusion, the above findings indicated that the growth and productivity of potato (Dagim variety) at study area can be improved by the combined application of blended NPSZnB fertilizer and CM.
\end{abstract}

Keywords: Blended fertilizer, Inorganic fertilizer, Organic fertilizer, Tuber yield

\section{INTRODUCTION}

Potato (Solanum tuberosum L.) belongs to the family of Solanaceae and genus Solanum (Haward, 1969). It is the most important vegetable crop, constituting the fourth most important food crop in the world following wheat, maize and rice and first among root and tuber crops (Douches, 2013). More than a billion people consume potatoes and the total global potato production exceeds 374 million metric tons per year. Potato has been highly recommended by the Food and Agriculture Organization (FAO) as a food security crop. Potato cropping systems help to improve resilience especially among smallholder farmers by providing direct access to nutritious food, increasing household incomes and reducing their vulnerability to food price volatility (André et al., 2014).

It is a high potential food security crop in Ethiopia due to its high yield potential, nutritional quality, short growing period and wider adaptability (Tewodros et al., 2014). It has been cultivated in Ethiopia for over 150 years; currently it is grown in many parts of the country. In Ethiopia, its meher season 
production area has reached about 66,926 ha, total production of $921,403.2$ ton cultivated by over 1.2 million households (CSA, 2017). On the other hand, the productivity of this crop in the country is very low (13.8 $\mathrm{t} \mathrm{ha}^{-1)}$ compared to the world's average yield of $19 \mathrm{t} \mathrm{ha}^{-1}$ (CSA, 2017).

Low actual yield of potato in Ethiopia is related to different factors, such as poor soil fertility (for example, low level of organic matter and /or low $\mathrm{pH}$, binding of phosphorus and not mineralizing nitrate), and sub-optimal fertilizer application rates are most determining factors (Haverkort et al., 2012). Soil fertility depletion owing to high rates of erosion is considered to be the fundamental biophysical root cause for declining per capita food production in Africa, including Ethiopia in the fields of smallholders (Tesfaye et al., 2011). Potato demands high levels of soil nutrients due to its relatively poorly developed, coarse, and shallow root system (Dechassa et al., 2003). The crop produces much more dry matter in a shorter life cycle that results in large amounts of nutrients removed per unit time, which generally most of the soils are not able to supply (Islam et al., 2013).

Thus far, soil fertility management research outputs using cattle manure and inorganic fertilizer is unavailable and has not been conducted at Banja District (Banja District Agriculture Office, 2017 annual report). On the contrary, soil of the study area is deficient in nitrogen, phosphorus, sulfur, zinc and boron nutrients as indicated in the Ethio-SIS map (ATA, 2015).

Application of organic manure and inorganic fertilizers could substantially influence the yield of potato (Biruk et al. 2015). Organic manures and their extracts have been reported to improve soil fertility, soil structure and furthermore help plants in combating pests and diseases (Khadem et al., 2010).

Although mineral NP fertilizers can be used to replenish soil nutrients and increase crop yields, concerns about soil exhaustion and nutritional imbalances, arising from increased and indiscriminate use of such fertilizers necessitate research on organic manure (Bayu et al., 2006). However, the use of organic fertilizer alone may not fully satisfy crop nutrient demand due to low available nutrient, relatively low nutrient content, high application rates and high labour requirements unless it is integrated with inorganic fertilizers (Peter et al., 2009). Therefore, integrated use of organic and inorganic fertilizers is important to improve soil fertility and in turn attain maximum yield. For example, in the nearby district (Burie), yields of $37 \mathrm{t} \mathrm{ha}^{-1}$ have been produced in an on farm demonstration activity (Tesfaye et al., 2015).

Fertilizer determination research works carried earlier have been limited to the two common macronutrients ( $\mathrm{N}$ and $\mathrm{P}$ ) and hence the effects of blended fertilizers have not been studied. New fertilizer materials with value addition and fortification with secondary and micronutrients would be required to ensure balanced fertilizer use involving most of the nutrients required by crops soil fertility status of a given areas. Balanced fertilization guarantees optimal crop production, better quality product and benefits growers and is also the best solution for minimizing the risk of nutrient imbalances. Nutrients such as N, P, K, S, B, Zn and others can often be included in new fertilizer formula (ATA, 2015). Use of balanced fertilizers in deficient soils can improve fertilizer-use efficiency and crop profitability.

Fertilizer use in Ethiopia has increased notably since 1990, but there is no concomitant attainable yield increase, especially in potato (Haverkort et al., 2012). This is mainly due to use of the two types of fertilizers (DAP and Urea) alone that may have resulted in unbalanced nutrient levels in the soil and use of specific area recommendation to wide areas (Chillot and Hassan, 2010). The effectiveness of cattle manure and other organic nutrient sources in maintaining soil fertility, improving crop yields and sustaining productivity when applied along with mineral fertilizers has been reported by different authors (Bayu et al., 2006). Cattle manure is among the easily accessible organic nutrient sources in the study zone due to high cattle population (Agegnehu et al., 2014). Despite the availability of CM in the crop-livestock farming systems of Awi zone, the use of CM for soil fertility maintenance and potato production is limited to homestead (Banja District Agriculture Office, 2017 annual report). Moreover, information on the effect of cattle manure application along with blended NPSZnB fertilizer on the growth, yield and quality of potato in Awi zone is not available (Banja District Agriculture Office, 2017 annual report). This study was therefore initiated to assess the effects of integrated use of cattle manure and blended NPSZnB fertilizer sources on growth, yield and quality of potato under Banja District. 


\section{Materials ANd Methods}

Description of the Experimental Site: The experiment was conducted in Amhara Region at Banja district of Awi Zone, Chewusa kebele farmers training center in 2017 under rain fed condition. The site is geographically located at $454 \mathrm{~km}$ North West of Addis Ababa at an elevation of 2560 meters above sea level and at latitude $10^{\circ} 57^{\prime} \mathrm{N}$ and longitude $36^{\circ} 56^{\prime} \mathrm{E}$. The experimental site receives 1700 $\mathrm{mm}$ average annual rainfall, $5^{\circ} \mathrm{C}$ minimum and $25^{\circ} \mathrm{C}$ maximum temperatures with nitisol soil type (Agegnehu et al., 2014).

Experimental Materials, treatments and experimental design: The experiment was conducted using the improved potato variety Dagim. This variety was released by Adet Agricultural Research Center (AARC) in 2012. It is characterized by white tuber skin color, shallow pink eye color, round tuber shape and erect growth habit. The treatments were set from different rates of blended NPSZnB fertilizer and cattle manure, CM (prepared from two to eight months of age). Sixteen treatments were obtained by combination of four NPSZnB fertilizer rates $\left(0,65.7 \mathrm{~kg} \mathrm{ha}^{-1}, 133 \mathrm{~kg} \mathrm{ha}^{-1}\right.$ and $\left.199 \mathrm{~kg} \mathrm{ha}^{-1}\right)$ which have been set based on $69 \mathrm{~kg} \mathrm{ha}^{-1} \mathrm{P}_{2} \mathrm{O}_{5}$ and $81 \mathrm{~kg} \mathrm{ha}^{-1} \mathrm{~N}_{2}$ recommendation (Tesfaye et al., 2015) and four levels of CM rates $\left(0,10 \mathrm{tha}^{-1}, 20 \mathrm{tha}^{-1}\right.$ and $\left.30 \mathrm{tha}^{-1}\right)$ which have been set based on $20 \mathrm{t} \mathrm{ha}^{-1}$ recommendation (Balemi, 2012). These treatments were tested in randomized complete block design (RCBD) with three replications.

Experimental Procedures: The land was well prepared and experimental plots were cultivated to the depth of 15 to $20 \mathrm{~cm}$ by oxen plow. The size of each plot was $2.4 \mathrm{~m} \mathrm{x} 3.75 \mathrm{~m}\left(9 \mathrm{~m}^{2}\right)$ and plots were leveled and ridges were prepared using hand tools to provide a medium fine soil for the growth of the crop. Each plot consists five rows that were $2.4 \mathrm{~m}$ length and spaced $75 \mathrm{~cm}$ apart and well sprouted medium size seed tubers were planted manually by placing in a row at spacing of $30 \mathrm{~cm}$ (EIAR, 2004). The two outer rows were considered as border. The blocks were separated by a $1.5 \mathrm{~m}$ distance whereas the unit plots were separated by one meter distance. Then seed tubers were hilled up with soil and buried at depth of $15 \mathrm{~cm}$ (Mohammad et al., 2013) in prepared ridges during the main cropping season after the rain commenced and the soil become moist enough to support emergence. Blended NPSZnB fertilizer was used as a source of mineral nutrients and full doses, which varied depending on treatments, was applied at time of sowing and cattle manure also used as sources of nutrients and full doses, which varied depending on treatments, was applied two weeks before sowing and thoroughly incorporated with the soil. The experiment was conducted under rain fed condition and agronomic practices were kept uniform for all treatments as recommended and adopted for the location.

Data Collected: Data collected on days to 50\% flowering, days to maturity, plant height, main stem number, leaf area index, total tuber yield, marketable tuber yield, tuber dry matter content specific gravity of tubers and tuber starch content and checked for normality and subjected to analysis of variance using SAS version 9.3 statistical software (SAS Institute Inc. 2012). The difference between treatments means were compared using least significant difference (LSD) at 5\% level of significance.

\section{RESULTS AND DISCUSSION}

Days to 50\% Flowering (DF): The number of days to 50\% flowering was highly significantly $(\mathrm{P}=0.001)$ influenced by blended NPSZnB fertilizer application, cattle manure $(\mathrm{CM})$ application and their interaction. The maximum period required to reach days to $50 \%$ flowering ( 73 days) was recorded from combined application of $133 \mathrm{~kg} \mathrm{ha}^{-1}$ blended NPSZnB fertilizer and $30 \mathrm{t} \mathrm{ha}^{-1}$ cattle manure which was statistically similar with application of $199 \mathrm{~kg} \mathrm{ha}^{-1}$ blended NPSZnB fertilizer and $30 \mathrm{t} \mathrm{ha}^{-1}$ cattle manure. The shortest duration to $50 \%$ flowering (57 days) was recorded from the control treatment, which was statistically in parity with applications of blended NPSZnB fertilizer of $65.7 \mathrm{~kg} \mathrm{ha}^{-1}, 133 \mathrm{~kg} \mathrm{ha}^{-1}$ and $199 \mathrm{~kg} \mathrm{ha}^{-1}$.

The significant difference among the treatments might be attributed to the characteristics of nitrogen and phosphorus nutrients which enhanced vegetative growth of the crop and prolonged days required to attain $50 \%$ of flowering. In addition, cattle manure may improve soil structure which increases nutrient uptake of crop and releases nutrients like nitrogen and phosphorus. In line with this, Alemayehu et al. (2015) and Biruk (2015) have also reported that increasing nitrogen and phosphorus fertilization levels significantly delayed days required reaching flowering in potato. 
Days to maturity (DM): The number of days to $75 \%$ maturity was highly significantly $(\mathrm{P}=0.001$ ) influenced by blended NPSZnB fertilizer application, cattle manure (CM) application and their interaction. The maximum period required to attain days to $75 \%$ maturity (97.67 days) was recorded from combined application of $199 \mathrm{~kg} \mathrm{ha}^{-1}$ blended NPSZnB fertilizer and $30 \mathrm{t} \mathrm{ha}^{-1}$ cattle manure which was statistically similar with application of $199 \mathrm{~kg} \mathrm{ha}^{-1}$ blended NPSZnB fertilizer and $20 \mathrm{t} \mathrm{ha}^{-1}$ cattle manure. While the shortest duration (86 days) was recorded from the control, $65.7 \mathrm{~kg} \mathrm{ha}^{-1}$ blended NPSZnB fertilizer application and $133 \mathrm{~kg} \mathrm{ha}^{-1}$ blended NPSZnB fertilizer applications alone.

This may be due to the fact that increased rate of nitrogen stimulated haulm growth, prolonged the growing period and delayed tuber formation (crop maturity). Therefore, a crop with more nitrogen will mature later in the season than a crop with less nitrogen because late growth (maturity) is related to excessive haulm development while early tuber growth (maturity) is related to less abundant haulm growth (Mulubrhan, 2004). Cattle manure increases soil moisture holding capacity and decrease leaching of nutrients, in addition to releasing nutrients like nitrogen and phosphorus. Phosphorus, sulfur and boron increases uptake of nitrogen since they are used for chlorophyll synthesis and initial root development (Rao et al., 2001). Alemayehu et al. (2015) and Biruk (2015) also reported that increasing nitrogen and phosphorus fertilization levels significantly delayed days required reaching flowering and maturity in potato.

Plant height (PH): Plant height was highly significantly $(P=0.001)$ influenced by blended NPSZnB fertilizer and cattle manure rate and significantly $(\mathrm{p}=0.04)$ affected by their interaction effect. The highest plant height $(63.73 \mathrm{~cm})$ was recorded from plants which grow with combined application of $199 \mathrm{~kg} \mathrm{ha}^{-1}$ blended NPSZnB fertilizer and $30 \mathrm{t} \mathrm{ha}^{-1}$ cattle manure. The shortest plant height $(36.5 \mathrm{~cm})$ was observed from control treatment. The significant increase in plant height observed by plants treated with combined use of highest rates of blended NPSZnB fertilizer and cattle manure could be due to the fact that nitrogen is considered as one of the major limiting nutrients in plant growth and the adequate supply of it promotes the formation of chlorophyll which in turn resulted in higher photosynthetic activity, vigorous vegetative growth and taller plants. Phosphorus is required in large quantities in shoot and root tips where metabolism is high and cell division is rapid. Similarly, sulfur promotes the formation of chlorophyll, higher photosynthetic activity, vigorous vegetative growth and taller plants. The presence of boron in the blended fertilizer nutrient source also significantly increased plant height due to its important role in the cell division and nitrogen absorption from the soil, enhancing plant growth ultimately increased plant height. Zinc enhances nitrogen uptake and metabolism, photosynthesis and chlorophyll synthesis (Potarzycki, 2009).

In addition to these, the current investigation is also consistent with the findings of Yourtchi et al. (2013), Alemayehu et al. (2015) and Biruk (2015) who indicated that plant height increased very significantly with increasing amount of nitrogen fertilizer in potato. Gezahegn (2011) has also reported that plant height increased in response to increased application rate of $\mathrm{N}$ and $\mathrm{P}$ fertilizers, which could be related to the role of nitrogen in promoting vegetative growth and that of phosphate in favoring leaf expansion and stem elongation.

Leaf area index (LAI): Leaf area index per hill was highly significantly $(\mathrm{P}=0.001)$ influenced by blended NPSZnB fertilizer application, cattle manure (CM) application and interaction of these two sources. The highest total leaf area index per hill (7.55) was recorded from combined application of $199 \mathrm{kgha}^{-1}$ blended NPSZnB fertilizer and $30 \mathrm{t} \mathrm{ha}^{-1}$ cattle manure. On the other hand, the lowest value for leaf area index per hill (1.73) was obtained from the control treatment. Application of $199 \mathrm{~kg} \mathrm{ha}^{-1}$ blended NPSZnB fertilizer and $30 \mathrm{t} \mathrm{ha}^{-1}$ cattle manure increased leaf area index by $336.42 \%$. Similarly, application of $199 \mathrm{~kg} \mathrm{ha}^{-1}$ blended NPSZnB fertilizer without cattle manure increased leaf area index by $242.7 \%$ and application of $30 \mathrm{t} \mathrm{ha}^{-1}$ cattle manure alone increased leaf area index by $172.83 \%$ over the control.

The reason for the increased leaf area index per hill could be attributed to development of more above ground biomass with the expanded leaves produced in response to nitrogen (Firew, 2014).

Phosphorus also promotes rapid canopy development, contributing to root cell division tuber set and starch synthesis. Cattle manure possibly improved soil physical properties such as bulk density and porosity (Garo et al., 2014), moisture holding capacity, thereby, promoted early root growth. Enhanced root growth could have enhanced the ability of plants to access nutrients. Sulfur, zinc and 
EFFECT of BLENDED Npsznb FERTILIZER and CATTLE Manure Rates on Growth, Yield and Quality of Potato (Solanum Tuberosum L.) at Banja District, Awi Zone, North Western Ethiopia

boron increases uptake of nitrogen since they are used for chlorophyll synthesis, activate enzymes, increase resistance to abiotic and biotic stresses and protection against oxidative damage (Potarzycki, 2009).

Table1. Days to 50\% flowering (DF), Days to maturity (DM), Plant height (PH) and Leaf area index (LAI) as influenced by application of blended NPSZnB fertilizer, cattle manure and interaction during the 2017 growing season at Chewusa, Banja district.

\begin{tabular}{|c|c|c|c|c|c|}
\hline \multicolumn{2}{|c|}{ Factors } & \multicolumn{4}{|c|}{ Variables } \\
\hline NPSZnB & Cattle Manure & DF & DM & PH $(\mathbf{c m})$ & LAI \\
\hline 0 & 0 & $57.00^{\mathrm{g}}$ & $86.00^{\mathrm{d}}$ & $36.50^{j}$ & $1.73^{\mathrm{k}}$ \\
\hline & 10 & $61.33^{f}$ & $90.67^{c}$ & $42.17^{i}$ & $2.10^{j}$ \\
\hline & 20 & $67.00^{\mathrm{d}}$ & $90.67^{\mathrm{c}}$ & $46.60^{\mathrm{h}}$ & $2.49^{i}$ \\
\hline & 30 & $71.67^{\mathrm{bc}}$ & $93.33^{\mathrm{b}}$ & $48.83^{\text {tgh }}$ & $2.99^{\mathrm{h}}$ \\
\hline 65.7 & 0 & $57.00^{\mathrm{g}}$ & $86.00^{\mathrm{d}}$ & $42.03^{i}$ & $2.66^{i}$ \\
\hline & 10 & $61.33^{f}$ & $90.67^{\mathrm{c}}$ & $50.63^{\mathrm{fg}}$ & $3.02^{\mathrm{h}}$ \\
\hline & 20 & $67.00^{\mathrm{d}}$ & $91.00^{\mathrm{c}}$ & $51.03^{\mathrm{et}}$ & $3.74^{\mathrm{t}}$ \\
\hline & 30 & $71.33^{\mathrm{c}}$ & $93.33^{b}$ & $53.70^{\text {de }}$ & $4.78^{\mathrm{d}}$ \\
\hline 133 & 0 & $57.67^{g}$ & $86.00^{\mathrm{d}}$ & $48.10^{\text {gh }}$ & $3.07^{\mathrm{gh}}$ \\
\hline & 10 & $64.67^{\mathrm{e}}$ & $90.67^{c}$ & $51.07^{\mathrm{ef}}$ & $3.36^{\mathrm{g}}$ \\
\hline & 20 & $67.00^{\mathrm{d}}$ & $91.67^{\mathrm{c}}$ & $54.50^{\mathrm{d}}$ & $4.67^{\mathrm{d}}$ \\
\hline & 30 & $73.00^{\mathrm{a}}$ & $91.05^{\mathrm{c}}$ & $59.00^{\mathrm{b}}$ & $6.20^{\mathrm{c}}$ \\
\hline 199 & 0 & $57.33^{\mathrm{g}}$ & $91.67^{\mathrm{c}}$ & $48.17^{\text {tgh }}$ & $4.20^{\mathrm{e}}$ \\
\hline & 10 & $64.67^{\mathrm{e}}$ & $90.67^{c}$ & $55.90^{\mathrm{cd}}$ & $4.85^{\mathrm{d}}$ \\
\hline & 20 & $71.00^{c}$ & $97.00^{\mathrm{a}}$ & $57.50^{b c}$ & $6.54^{\mathrm{b}}$ \\
\hline & 30 & $72.67^{\mathrm{ab}}$ & $97.67^{\mathrm{a}}$ & $63.73^{\mathrm{a}}$ & $7.55^{\mathrm{a}}$ \\
\hline LSD (5\%) & & 1.10 & 1.20 & 2.92 & 0.29 \\
\hline $\mathrm{CV}(\%)$ & & 1.02 & 1.60 & 3.30 & 3.74 \\
\hline
\end{tabular}

Means in the column followed by the same letter(s) are not significantly different at $5 \%$ level of significance. LSD $(0.05)=$ Least significant difference at $5 \%$ level and CV $(\%)=$ coefficient of variation in percent.

Marketable tuber yield (MTY): Marketable tuber yield was highly significantly ( $\mathrm{P}=0.007$ ) influenced by the application of blended NPSZnB fertilizer, cattle manure (CM) and their interaction. The highest marketable tuber yield $\left(31.7 \mathrm{t} \mathrm{ha}^{-1}\right)$ was obtained from the combined application of $199 \mathrm{~kg}$ $\mathrm{ha}^{-1}$ blended NPSZnB fertilizer and $30 \mathrm{t} \mathrm{ha}^{-1}$ cattle manure. While, the lowest yield $\left(9.81 \mathrm{t} \mathrm{ha}^{-1}\right)$ was recorded from the control treatment. The combined application of $199 \mathrm{~kg} \mathrm{ha}^{-1}$ blended NPSZnB fertilizer and $30 \mathrm{t} \mathrm{ha}^{-1}$ cattle manure increased marketable tuber yield by $62.8 \%$ over $199 \mathrm{~kg} \mathrm{ha}^{-1}$ blended NPSZnB fertilizer alone, $119.4 \%$ over $30 \mathrm{t} \mathrm{ha}^{-1}$ cattle manure alone and $223.1 \%$ over the control. Increasing rate of blended NPSZnB fertilizer and cattle manure alone also positively influenced marketable tuber weight.

The possible reason for the highest marketable tuber yield observed from the combined application of inorganic and organic fertilizer was related with the increased nutrients in the soil that resulted in better vegetative growth which in turn enabled the crop to produce greater photosynthate. Increase in marketable tuber yield with increasing rates of blended NPSZnB fertilizers was due to the positive effect of both nitrogen and phosphorus on marketable tuber weight (Israel et al., 2012). This could be attributable to the fact that in such conditions, vegetative growth of the aerial parts can be enhanced and translocation of photosynthetic matters in to the storage parts increased (Alemayehu et al., 2015). The current finding is in line with investigations of Alemayehu et al. (2015) and Yourtchi et al. (2013) who reported that nitrogen fertilization significantly influenced marketable tuber yield. Zelalem et al. (2009) and Israel et al. (2012) also reported that $\mathrm{N}$ and $\mathrm{P}$ fertilization significantly influenced productivity of potato measured in terms of marketable and total tuber yields.

Total tuber yield (TTY): Total tuber yield was highly significantly $(\mathrm{P}=0.001)$ influenced by the application of blended NPSZnB fertilizer and cattle manure (CM) independently, and significantly $(\mathrm{P}=0.04)$ affected by the interaction of these two sources. The highest total tuber yield $\left(34.1 \mathrm{tha}^{-1}\right)$ was obtained from the combined application of $199 \mathrm{k} \mathrm{gha}^{-1}$ blended NPSZnB fertilizer and $30 \mathrm{tha}^{-1}$ cattle manure, however, this result was statistically similar with the combined application of $199 \mathrm{~kg}$ 
$\mathrm{ha}^{-1}$ blended NPSZnB fertilizer and $20 \mathrm{tha}^{-1}$ cattle manure. On the other hand, the lowest total tuber yield $\left(12.29 \mathrm{t} \mathrm{ha}^{-1}\right)$ was recorded from the control treatment.

Combined application of $199 \mathrm{~kg} \mathrm{ha}^{-1}$ blended NPSZnB fertilizer and $30 \mathrm{t} \mathrm{ha}^{-1}$ cattle manure increased total tuber yield by $44.31 \%$ over $199 \mathrm{~kg} \mathrm{ha}^{-1}$ blended NPSZnB fertilizer alone, $84.32 \%$ over $30 \mathrm{t} \mathrm{ha}^{-1}$ cattle manure alone and $177.46 \%$ over the control. Increasing rate of blended NPSZnB fertilizer and cattle manure alone also positively influenced total tuber yield. The possible reasons for the highest total tuber yield observed from the combined application of blended NPSZnB fertilizer and cattle manure was related with increased nutrients in the soil and modification of soil environment that resulted in better vegetative growth which in turn enabled the crops to produce greater photosynthate of the crop. Increasing in total tuber yield with increasing rates of blended NPSZnB fertilizer was due to the positive effect of both nitrogen and phosphorus on total tuber weight (Israel et al., 2012). This is probably attributed to the improvement in conditions that enhanced vegetative growth of the aerial parts and, hence, translocation of photosynthate into the storage parts (Alemayehu et al., 2015). Similarly, total tuber yield and marketable tuber yield increased significantly as the rate of sulfur increased, probably due to sulfur's role in the synthesis of sulfur containing amino acids, proteins, energy transformation, activation of enzymes which in turn enhances carbohydrate metabolism and photosynthetic activity of plant with increased chlorophyll synthesis (Juszczuk and Ostaszewska, 2011). Zinc exerts a great influence on basic plant life processes, such as: nitrogen metabolism and uptake of nitrogen and protein quality; photosynthesis and chlorophyll synthesis (Potarzycki, 2009) which resulted in high marketable and total tuber yield. Boron application showed significant increase in yield in this study probably due to its role in regulation of carbohydrate metabolism and its transport within the plant besides the synthesis of amino acids and proteins (Debnath and Ghosh, 2011). This result is in agreement with the findings of Alemayehu et al. (2015) and Yourtchi et al. (2013) who reported that application of nitrogen significantly increases both total and marketable tuber yield. Firew (2014) and Israel et al. (2012) also reported that total tuber yield was highly significantly influenced by nitrogen and phosphorus.

Table2. Marketable tuber yield (MTY) and total tuber yield (TTY) as influenced by application of blended NPSZnB fertilizer, cattle manure and interaction during the 2017 growing season at Chewusa, Banja district.

\begin{tabular}{|c|c|c|c|}
\hline \multicolumn{4}{|c|}{ Factors } \\
\hline NPSZnB & Cattle Manure & $\operatorname{MTY}\left(\mathrm{t} \mathrm{ha}^{-1}\right)$ & TTY $\left(\mathrm{t} \mathrm{ha}^{-1}\right)$ \\
\hline 0 & 0 & $9.81^{\mathrm{i}}$ & $12.29^{k}$ \\
\hline & 10 & $13.79^{\mathrm{h}}$ & $17.66^{j}$ \\
\hline & 20 & $13.89^{\mathrm{h}}$ & $18.04^{\mathrm{j}}$ \\
\hline & 30 & $14.45^{\mathrm{h}}$ & $18.50^{i j}$ \\
\hline 65.7 & 0 & $13.61^{\mathrm{h}}$ & $17.29^{j}$ \\
\hline & 10 & $15.14^{\mathrm{gh}}$ & $21.73^{\mathrm{gh}}$ \\
\hline & 20 & $17.77^{\mathrm{gf}}$ & $21.72^{\text {gh }}$ \\
\hline & 30 & $18.61^{\mathrm{f}}$ & $23.00^{\mathrm{gh}}$ \\
\hline 133 & 0 & $18.17^{\mathrm{t}}$ & $21.00^{\mathrm{hi}}$ \\
\hline & 10 & $21.63^{\mathrm{de}}$ & $26.70^{\mathrm{de}}$ \\
\hline & 20 & $22.35^{\mathrm{d}}$ & $26.23^{\text {ef }}$ \\
\hline & 30 & $25.97^{\mathrm{bc}}$ & $29.07^{\mathrm{cd}}$ \\
\hline 199 & 0 & $19.47^{\text {ef }}$ & $23.63^{\mathrm{tg}}$ \\
\hline & 10 & $24.05^{\mathrm{cd}}$ & $29.83^{\mathrm{bc}}$ \\
\hline & 20 & $27.85^{b}$ & $31.82^{\mathrm{ab}}$ \\
\hline & 30 & $31.70^{\mathrm{a}}$ & $34.10^{\mathrm{a}}$ \\
\hline LSD (5\%) & & 2.78 & 2.62 \\
\hline $\mathrm{CV}(\%)$ & & 8.31 & 6.45 \\
\hline
\end{tabular}

Tuber dry matter content $(\%)$ : Tuber dry matter content was highly significantly $(\mathrm{P}=0.001)$ affected by blended NPSZnB fertilizer, cattle manure and interaction of these two nutrient sources. The highest tuber dry matter content $(24.37 \%)$ was obtained from the control treatment. On the other hand, the lowest tuber dry matter content $(17.13 \%)$ was recorded from the combined application of $199 \mathrm{~kg}$ ha-1 blended NPSZnB fertilizer and $30 \mathrm{t}$ ha- 1 cattle manure.

The tuber dry matter content of the control treatment was $42.27 \%$ greater than the combined application of $199 \mathrm{~kg} \mathrm{ha}^{-1}$ blended NPSZnB fertilizer and $30 \mathrm{t} \mathrm{ha}^{-1}$ cattle manure. Application of 199 
$\mathrm{kg} \mathrm{ha}^{-1}$ blended NPSZnB fertilizer alone, reduced tuber dry matter content from $24.37 \%$ to $22.07 \%$ and application of $30 \mathrm{t} \mathrm{ha}^{-1}$ cattle manure alone, reduced tuber dry matter content from $24.37 \%$ to $19.33 \%$. The possible reason for the highest tuber dry matter content observed from the control treatment and the difference for each treatment may be associated with high nitrogen and micro nutrients application that may have resulted in low partitioning of assimilate to tubers and phosphorus that have inverse relation with tuber dry matter content. This result is in line with the results of Zelalem et al., (2009) and Israel et al. (2012) who reported that high nitrogen level and phosphorus reduces the dry matter content of potato tubers.

Tuber starch content (\%): Tuber starch content per $100 \mathrm{~g}$ was significantly $(\mathrm{P}=0.03)$ influenced by blended NPSZnB fertilizer application, cattle manure application and their interaction. The highest tuber starch content $(15.7 \mathrm{~g} / 100 \mathrm{~g})$ was obtained from the control treatment. On the other hand, the lowest tuber starch content $(8.4 \mathrm{~g} / 100 \mathrm{~g})$ was obtained from the combined application of $199 \mathrm{~kg} \mathrm{ha}{ }^{-1}$ blended NPSZnB fertilizer and $30 \mathrm{t} \mathrm{ha}^{-1}$ cattle manure.

The starch content recorded from the control treatment was $86.90 \%$ greater than that obtained from the combined application of $199 \mathrm{~kg} \mathrm{ha}^{-1}$ blended NPSZnB fertilizer and $30 \mathrm{t} \mathrm{ha}^{-1}$ cattle manure. The possible reason may be the fact that nitrogen application might have resulted in low partitioning of assimilate to tubers and availability of sulfur, zinc and boron facilitates uptake and use efficiency of plants to nitrogen. In addition, cattle manure increases availability of nitrogen and phosphorus by favoring soil physicochemical property and releasing nitrogen, phosphorus and other nutrients $(\mathrm{S}, \mathrm{Zn}$, B etc). This result is in line with the results of Mousavi et al. (2007) and Verma et al. (2005) who reported that high nitrogen and organic matter level decreases starch content of potato tuber.

Table3. Tuber dry matter content (TDMC) and tuber starch content (TSC) as influenced by application of blended NPSZnB fertilizer, cattle manure and interaction during the 2017 growing season at Chewusa, Banja district.

\begin{tabular}{|c|c|c|c|}
\hline Factors & & & \\
\hline NPSZnB & Cattle Manure & TDMC $(\%)$ & TSC (\%) \\
\hline 0 & 0 & $24.37^{\mathrm{a}}$ & $15.70^{\mathrm{a}}$ \\
\hline & 10 & $22.37^{\mathrm{c}}$ & $15.34^{\mathrm{a}}$ \\
\hline & 20 & $20.73^{\mathrm{d}}$ & $13.27^{\mathrm{abc}}$ \\
\hline & 30 & $19.33^{\mathrm{e}}$ & $9.45^{\mathrm{bcd}}$ \\
\hline 65.7 & 0 & $23.27^{\mathrm{b}}$ & $13.81^{\mathrm{ab}}$ \\
\hline & 10 & $22.07^{\mathrm{c}}$ & $13.54^{\mathrm{abc}}$ \\
\hline & 20 & $21.00^{\mathrm{d}}$ & $13.73^{\mathrm{abc}}$ \\
\hline & 30 & $18.93^{\mathrm{e}}$ & $9.29^{\mathrm{cd}}$ \\
\hline 133 & 0 & $22.56^{\mathrm{bc}}$ & $9.79^{\mathrm{bcd}}$ \\
\hline & 10 & $20.67^{\mathrm{d}}$ & $11.38^{\mathrm{abc}}$ \\
\hline & 20 & $20.60^{\mathrm{d}}$ & $10.78^{\mathrm{bcd}}$ \\
\hline & 30 & $18.17^{\mathrm{f}}$ & $9.68^{\mathrm{bcd}}$ \\
\hline & 0 & $22.07^{\mathrm{c}}$ & $12.93^{\mathrm{abc}}$ \\
\hline & 10 & $20.63^{\mathrm{d}}$ & $10.81^{\mathrm{bcd}}$ \\
\hline & 20 & $20.47^{\mathrm{d}}$ & $10.04^{\mathrm{bcd}}$ \\
\hline LSD (5\%) & 30 & $17.13^{\mathrm{g}}$ & $8.40^{\mathrm{d}}$ \\
\hline CV (\%) & & 0.7 & 4.52 \\
\hline
\end{tabular}

Means in the column followed by the same letter(s) are not significantly different at $5 \%$ level of significance. LSD $(0.05)=$ Least significant difference at $5 \%$ level and CV $(\%)=$ coefficient of variation in percent.

Specific gravity $\left(\mathbf{g} / \mathrm{cm}^{3}\right)$ : The specific gravity of tubers was significantly $(\mathrm{P}=0.012)$ affected by blended NPSZnB fertilizer and highly significantly $(\mathrm{P}=0.002)$ affected by cattle manure. However, there was no significant $(\mathrm{P}=0.16)$ effect from the interaction of blended NPSZnB fertilizer and cattle manure application. The maximum tuber specific gravity (1.089) was obtained from control treatment which is statistically not different from application of $65.7 \mathrm{~kg} \mathrm{ha}^{-1}$ blended NPSZnB fertilizer, $133 \mathrm{~kg}$ $\mathrm{ha}^{-1}$ blended NPSZnB fertilizer, $10 \mathrm{t} \mathrm{ha}^{-1}$ cattle manure and $20 \mathrm{t} \mathrm{ha}^{-1}$ cattle manure. On other hand the, 
lowest value was recorded from application of $199 \mathrm{~kg} \mathrm{ha}^{-1}$ blended NPSZnB fertilizer and $30 \mathrm{t} \mathrm{ha}^{-1}$ cattle manure. This might be due to the fact that nitrogen decreases the solid constituent of tuber and increases the water content of tubers and this result agrees with Kandil et al. (2011) who found the highest specific gravity (1.064) from treatment combination of $60 \%$ mineral nitrogen $\left(238 \mathrm{~kg} \mathrm{~N} \mathrm{ha}^{-1}\right)$ and $40 \%$ organic cattle manure $\left(158 \mathrm{~kg} \mathrm{~N} \mathrm{ha}^{-1}\right)$.

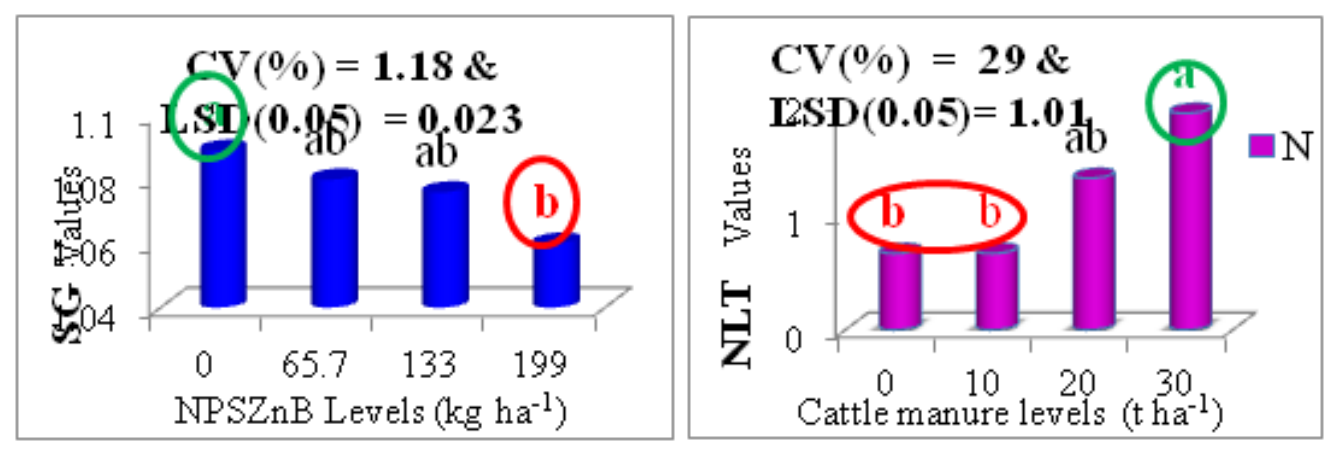

Figure1. Main effects of blended NPSZnB fertilizer and cattle manure on specific gravity (SG)

\section{SUMMARY AND CONCLUSION}

Potato (Solanum tuberosum L.) is one of the most popular and widely cultivated vegetable crops in Ethiopia. It grows in short period, staple food and income source for small holder farmers. A study was conducted to investigate the effects of combined application of blended NPSZnB fertilizer and cattle manure rates on growth, yield and quality of potato at Banja district of Awi zone, Northwestern Ethiopia. The experiment was set as a 4 x 4 factorial with four levels of blended NPSZnB fertilizer $(0$, 65.7, 133 and $\left.199 \mathrm{~kg} \mathrm{ha}^{-1}\right)$ and four levels of cattle manure $\left(0,10,20\right.$ and $\left.30 \mathrm{t} \mathrm{ha}^{-1}\right)$ with three replications. Data on growth, yield and quality variables were collected and analyzed using SAS Version 9.3. The result indicated that application of blended NPSZnB fertilizer in combination with cattle manure was found to be important for the growth, yield and quality of potato in the study area. Application of blended NPSZnB fertilizer and cattle manure resulted in better performances for some growth, yield and quality variables.

The results indicated that a combined application of blended NPSZnB fertilizer and cattle manure showed significant increase in days to flowering, days to maturity, plant height, leaf area index, marketable tuber yield and total tuber yield, while application of combined blended NPSZnB fertilizer and cattle manure resulted in significant reduction in tuber dry matter content and tuber starch content. The combined application of $199 \mathrm{~kg} \mathrm{ha}^{-1}$ blended NPSZnB fertilizer and $30 \mathrm{t} \mathrm{ha}^{-1}$ cattle manure resulted in longest days to maturity $(97.67$ days), longest plant height $(63.73 \mathrm{~cm})$, largest leaf area index (7.55), maximum marketable tuber yield $\left(31.7 \mathrm{tha}^{-1}\right)$ and maximum total tuber yield ( $\left.34.1 \mathrm{t} \mathrm{ha}^{-1}\right)$.

Increasing application rates of blended NPSZnB fertilizer alone from zero to $199 \mathrm{~kg} \mathrm{ha}^{-1}$ resulted in significant increase in days to flowering, days to maturity, plant height, leaf area index, marketable tuber number, marketable tuber yield and total tuber yield. Increasing the application rates of cattle manure fertilizer alone from zero to $30 \mathrm{t} \mathrm{ha}^{-1}$ resulted in significant increase in days to flowering, days to maturity, plant height, leaf area index, marketable tuber yield and total tuber yield, but number of main stem and unmarketable tuber yield were not affected by blended NPSZnB fertilizer, cattle manure application and interaction. More importantly, total tuber yield was highly significantly and positively correlated with plant height, leaf area index and marketable tuber yield. Generally the strong positive correlation was observed among most growth and yield variables of potato.

According to the current investigation, combined application of $199 \mathrm{~kg} \mathrm{ha}^{-1}$ blended NPSZnB fertilizer and $30 \mathrm{t} \mathrm{ha}^{-1}$ cattle manure fertilizer gave best result in terms of growth and yield variables of potato. Additionally, the integrated approach has a long term benefit in that it also improves the physicochemical properties of the soil for sustainable crop production.

\section{ACKNOWLEDGEMENT}

We would like to thank Pawe Agricultural Research Center (Horticulture Research and Laboratory Research group), Adet Agricultural Research Center and Banja district Agriculture and Rural Development Office for their collaboration and support in provision of the necessary planting material and other relevant services to carry out this work smoothly. 


\section{REFERENCES}

[1] Agegnehu Shibabaw, Getachew Alemayehu, Yigzaw Desalegn, Enyew Adgo, Yoseph Tewodros and Yeshitla Merene, 2014. Exploratory Survey on Climate Change Effects, Value Chain Processes and Supportive Services: Case Study from Potato Based Farming System of Awi-Zone, Ethiopia. International Journal of Agriculture Innovations and Research Volume 2, Issue 4, ISSN (Online) pp.2319-1473.

[2] Alemayehu, T.G., Nigussie, D. and Tamado, T., 2015. Response of potato (Solanum tuberosum L.) yield and yield components to nitrogen fertilizer and planting density at Haramaya, Eastern Ethiopia. Journal of Plant Sciences, 3(6):pp.320-328.

[3] André, D., Peter, K. and Oscar O., 2014. Potatoes for Sustainable Global Food Security. European Association for Potato Research, 57 (3-4): pp.185-199.

[4] Bayu, W., Rethman, N.F., Hammes, P.S. and Alemu, G., 2006. Effects of Farmyard Manure and Inorganic Fertilizers on Sorghum Growth, Yield, and Nitrogen Use in a Semi-Arid Area of Ethiopia. Journal of Plant Nutrition, 29: pp.391-407.

[5] Biruk, M., Nigussie, D., Tamado, T., Yibekal, A and Bekele, A., 2015. The Effects of combined Application of cattle manure and NP Fertilizers on Yield and Nutrient Uptake of Potato in North Eastern Ethiopia. Department of Plant Science, College of Agriculture and Environmental Science, Haramaya University, P. O. Box 138, Dire Dawa, Ethiopia.

[6] Chillot Yirga and Hassan, R.M., 2010. Social Costs and incentives for optimal control of soil nutrient depletion in the central highland of Ethiopia. Agricultural system, 103: pp.153-160.

[7] CSA, 2017. Agricultural Sample Survey Report on Area and Production (Private Peasant Holdings Meher Season. Central Statistical Agency of Ethiopia, Statistical Bulletin.

[8] Debnath and Ghosh, 2011. Response of Boron and Zinc Fertilization to Productivity of Rice in Piedmont Soil of Arunachal Pradesh

[9] Dechassa, N., Schenk, M.K. and Steingrobe, N., 2003. Phosphorus efficiency of cabbage (Brassica oleraceae L. var. capitata), carrot (Daucus carota L.), and potato (Solanumtuberosum L). Plant and Soil, 250: pp.215-224.

[10] Douches, D.S. 2013. Breeding and genetics for the improvement of potato (solanum tuberosum L.) for yield, quality and pest resistance. http://potatobg.msu.edu/program moverview.shtml.

[11] Firew, G. W., 2014. Response of potato (solanum tuberosum 1.) to nitrogen and phosphorus application under irrigation in Dire Dawa, eastern Ethiopia. A thesis submitted to the

[12] Garo, G., Gedebo, A. and Kena, K., 2014. Combined effects of inorganic (NP) and farm yard manure (FYM) fertilizers on root yield and above ground biomass of sweet potato (Ipomoea batatas(1.) lam.) at Delbo watershed Wolaita zone, Southern Ethiopia. Journal of Scientific Research and Reviews, 3(2): pp.028-033.

[13] Gezahegn, W., 2011. Response of Potato (solanum tuberosum 1.) to Application of Nitrogen, Phosphorus, and Farmyard Manure at Debark, Northwestern Ethiopia. M.Sc. Thesis, Haramaya University, Ethiopia.

[14] Haverkort, A.J., Koesveld, M.J., van Schepers, H.T.A.M., Wijnands, J.H.M., Wustman, R. and Zhang, X.Y., 2012. Potato prospects for Ethiopia: on the road to value addition. Lelystad: PPO-AGV, 2012 (PPO publication 528), 66p.

[15] Haward, H.W., 1969. Genetics of potato (Solanum tuberosum L.) Logos press Ltd., Cambridge, England pp.1-7.

[16] Islam, Md.M., Akhter S., Majid N.M., Ferdous J. and Alma M.S., 2013. Integrated nutrient management for potato (Solanum tuberosum) in grey terrace soil (Aric Albaquipt). Australian Journal of Crop Science, 7(9): pp.1235-1241.

[17] Israel Zewide, Ali Mohammed and Solomon Tulu, 2012. Effect of different rates of nitrogen and phosphorous on yield and yield components of potato (Solanum tuberosum L.) at Masha District, Southwestern Ethiopia. International Journal of Soil Science, 7(4): pp.146-156.

[18] Juszczuk, I.M. and Ostaszewska, M., 2011. Respiratory activity, energy and redox status in sulphurdeficient bean plants. Environmental and Experimental Botany, 74:pp.245-254.

[19] Khadem, S.A., Galavi, M., Ramrodi, M., Mousavi, S.R., Rousta, M.J., Rezvani-Moghadam, P., 2010. Effect of animal manure and superabsorbent polymer on corn leaf relative water content, cell membrane stability and leaf chlorophyll content under dry condition. Aus. J. Crop Sci. 4 (8): pp.642-647.

[20] Mulubrhan Haile, 2004. The Effect of N, P, K Fertilization on Yield and Yield Components of Potato (Solanum tuberosum L.) Grown on Vertisols of Mekelle Area, Ethiopia. M.Sc. Thesis, the University of Haremaya, pp.15. 
[21] Peter R. Gildemacher, Wachira Kaguongo, Oscar Ortiz , Agajie Tesfaye, Gebremedhin Woldegiorgis, William W. Wagoire, Rogers Kakuhenzire, Peter M. Kinyae ,Moses Nyongesa, Paul C. Struik and Cees Leeuwis, 2009. Improving Potato Production in Kenya, Uganda and Ethiopia: Potato Research 52:pp.173-205.

[22] Potarzycki, J. and Grzebisz W., 2009, Effect of zinc foliar application on grain yield of maize and its yielding components. Plant Soil Environ, 55(12): pp.519-527.

[23] Rao S, Singh KK, Ali M., 2001. Sulphur: A key nutrient for higher pulse production. Fert. News 46:pp.3148.

[24] Tesfaye Abebe, Asresie Hassen, Alemu Worku, Molla Tafere, Mekonen Tolla, Abel Ahmed, Seferew Dagnew, Yihenew G.Selassie and Desallegn Molla, 2015. Best fit practice manual for potato production and utilization.

[25] Tesfaye Abebe, Githiri M., Dereraand J. and Debele T. 2011. Subsistence farmers' experiences and perceptions about soil and fertilizer use in western Ethiopia. Ethiop. Journal of Applied Science and Technology, 2(2): pp.61-74.10-240.

[26] Tewodros, A., Paul, C. Struik and Adane, H., 2014. Characterization of seed potato (Solanum tuberosum 1.) Storage, pre-planting treatment and marketing systems in Ethiopia: the case of westarsizone. African journal of agricultural research, 9(15): pp.1218-1226.

[27] Yourtchi, M.S., Hadi, M.H.S. and Darzi, M.T. 2013. Effect of nitrogen fertilizer and vermicompost on vegetative growth, yield and NPK uptake by tuber of potato (Agria CV.). International Journal of Agriculture and Crop Sciences, 5(18): pp.2033-2040.

[28] Zelalem, A., Tekalign, T. and Nigussie, D., 2009. Response of potato (Solanum tuberosum L.) to different rates of nitrogen and phosphorus fertilization on vertisols at Debre Berhan, in the central highlands of Ethiopia. African Journal of Plant Science, 3(2):pp.016-024.

Citation: Bewket Getachew Bekele, "EFFECT of BLENDED Npsznb FERTILIZER and CATTLE Manure Rates on Growth, Yield and Quality of Potato (Solanum Tuberosum L.) at Banja District, Awi Zone, North Western Ethiopia” International Journal of Research Studies in Agricultural Sciences (IJRSAS), 2019; 5(5), pp. 27-36, http://dx.doi.org/10.20431/2454-6224.0505004

Copyright: (c) 2019 Authors. This is an open-access article distributed under the terms of the Creative Commons Attribution License, which permits unrestricted use, distribution, and reproduction in any medium, provided the original author and source are credited. 